\title{
The application of interactive Task-Based Learning for EFL students
}

\author{
Eny Syatriana*1, Ardiansyah ${ }^{2}$, Richard Orem $^{3}$ \\ ${ }^{1}$ Universitas Muhammadiyah Makassar, Makassar, Indonesia \\ e-mail: *enysyatriana@yahoo.com \\ ${ }^{2}$ Sekolah Menengah Atas 16 Makassar, Makassar, Indonesia \\ e-mail: ardiansyahardy806@gmail.com \\ ${ }^{3}$ Northern Illinois University, United States \\ e-mail: rorem@niu.edu
}

\begin{abstract}
Speaking plays an essential role in the production of a variety of languages, it can be in the form of discussions, speeches, debates, argumentation, conversation, storytelling and retelling. However, this study aims to develop a learning strategy based on TaskBased Learning that can improve speaking ability. The Research questions are (1) what learning strategy is appropriate to increase the students speaking skills? (2) How is the student achievement under the implementation of task-based learning (3) is the application of task-based learning effective in improving students' ability to speak? The study consists of (1) need analysis, (2) design strategy, (3) implementation, and (4) evaluation. The study will be implemented in three steps using the design development research. The principles and procedures are using qualitative and quantitative. The participant of the research was a speaking class subject of UNISMUH. The study concludes that although the participants have shown their ability to speak using taskbased learning improvement is needed to increase fluency, accuracy, flexibility, comprehensibility appropriately and effectively to make their speaking better. Recommendation to English lecturer also given as pedagogical implication of this study.
\end{abstract}

\section{Keywords:}

Learning model; task-based learning; speaking; development

\section{INTRODUCTION}

Performing spoken English for fresh graduate students of Unismuh Makassar can be a challenging task for some students as they may result in incompetence using English, English in Indonesia is a foreign language, students learn in the classroom no longer used in the community (Hamra \& Syatriana, 2010; Syatriana, Husain, Haryanto, \& Jabu, 2013). This condition creates a big problem for an English learner to master the language. This situation calls the teacher or educator attention to finding the solution based on the researcher experience to observe the classroom. Most students did not follow the class effectively some teacher still focus using textbooks and not deals to students' 
thoughts, feelings, and their progress, with reference above this study want to measure students ability in speaking.

Most students have not learned how to communicate in English appropriately. Silberman (1996) revealed that students only can read, memorize vocabulary, write, and remember English rules. Speaking is an activity to tell expressions, ideas, opinions, feelings by using language (Nunan, 2016; Nunan \& Richards, 2015). Nunan (2018) says that speaking is a communication process in which the aim is to exchange information, thoughts, and ideas, with others both formally and informally. In this context, he also stresses that the essential thing in speaking is the arrival of messages and information from the speaker to the listener and the listener can provide feedback when necessary. This research thus aims to apply learning model based on Task-Based learning which is implemented as an effort to improve students' English speaking skills of English Department of Unismuh Makassar, furthermore, the current students have low skill in speaking. Thus TBL is indicating that it has been an exciting area of research to apply. TBL offers students an opportunity to do precisely the primary focus of classroom activity, the task and language is the instrument which the students use to complete it. The task is an activity in which students use language to achieve a specific outcome which the activity reflects the real life. The activity reflects real life and learners focus on meaning; they are free to use any language they want. Playing a game, solving a problem or sharing information or experiences, can all be considered as relevant and authentic tasks. In TBL an activity in which students are given a list of words to use cannot be considered as a particular task. Nor can a typical roleplay if it does not contain a problem-solving element or where students are not given a goal to reach. In many roleplays, students merely act out their limited role. For instance, a role play where students have to act out roles as company directors but must come to an agreement or find the right solution to meet the aim of TBL.

The tasks will generate their language and create an opportunity for language acquisition (Krashen, 2015; Lao \& Krashen, 2014; Saville-Troike \& Barto, 2016). If we can take the focus away from and structures, we can develop our students' ability to do things in English. That is not to say that there will be no attention paid to accuracy, work on language is included in each task and feedback, and language focus have their places in the lesson plans. We feel that teachers have a responsibility to enrich their students' language when they see it is necessary but students should be given the opportunity to use English in the classroom as they use their languages in everyday life. The task model follows Willis (1996) for the different phases of the task. According to Willis, there are different task phases as the "pre-task," "task-cycle," and "language focus." In the first phase, the instructor (the coauthor) introduces the topic, models the task, and recalls language. In the second phase, task-cycle sees the students working in pairs or groups to complete tasks given by the teacher. During the applications, the instructor monitors the students and guides them. Then, the students prepare and report to the whole class while the teacher observes and gives positive feedback. A steadiness should be kept between fluency, which is what the task provides, 
and accuracy, which is provided by task feedback. Thus, this study will cover finding of best learning strategy, students' achievement of TBL and the effectiveness of TBL to improve students' ability in speaking.

\section{METHOD}

In this study, a mixed method that includes both quantitative and qualitative procedures has been applied to collect analyzing data from the participant. The study can also be categorized as a research and development. The researcher has implemented TBL activities in the classroom. The researcher conducted in the fifth-semester student of English department of Unismuh in academic 2016-2017. The participant has 30 students who participated actively. In general, the development procedure consists of three stages: Problem identification, Design, and Development Gustafson and Branch (2002) simplified in the following Figure 1.

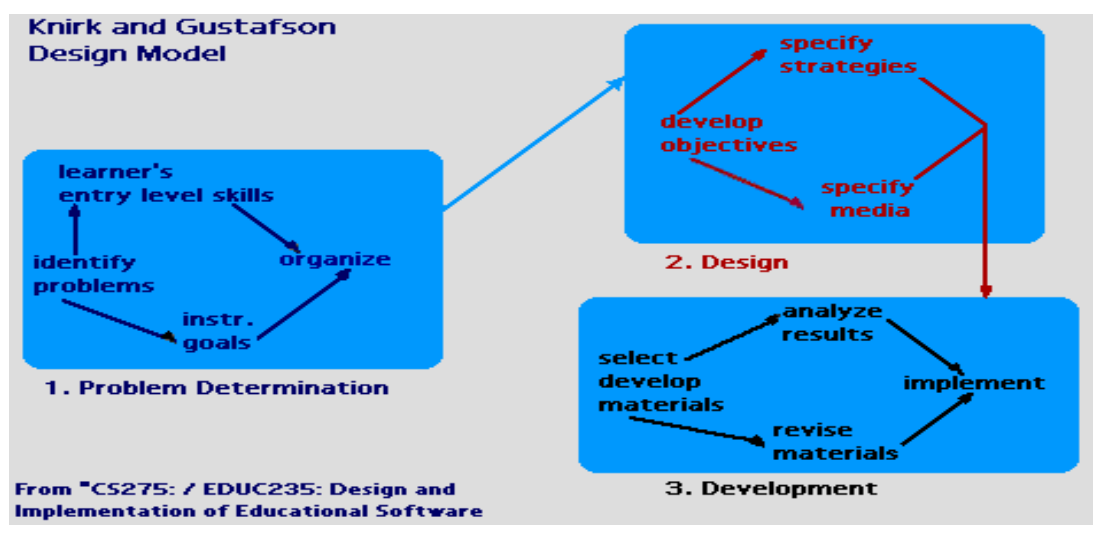

Figure 1. Knirk and Gustafson Design Model

a) In the problem identification stage, literature study is done and needs analysis; (2) design stage to create the draft model; (3) development stage, developing and editing products; at the evaluation, stage held formative and summative evaluation.

b) The objective of design is to describe the needs and characteristics of the field which relates to the development of learning speaking model. It includes speaking course descriptions, syllabus and Learning Design based on TBL, Furthermore, to design learning model which is associated to some essential concepts in creating a learning environment that provides high motivation in speaking activity.

c) To define the concepts that can be used to improve the learning process. So, the students can improve their speaking skills. Furthermore, the speaking prototype would be validated before being implemented in the learning process. The objective in the development stage is, to test the prototype models extensively with teaching materials in the first step in two trial classes. The tests were pretest and posttest. The tests are given to see the effectiveness of the learning model. 
Atkinson and Longman (2002) divides the four necessary competencies that must be mastered by language learners, namely: listening, speaking, reading and writing. Writing and speaking are output while reading and listening are the inputs. They must be trained to produce excellent output. Each subject in school has its characteristics, different from other subjects. In language learning, the diversity lies in the function of language as a communication tool. This means that learning a language is not just learning vocabulary or grammar regarding knowledge, but also learning to apply this knowledge to communication activities. Therefore, a student cannot be said to master the language only because getting good marks for vocabulary or grammar but he cannot speak. Students' ability to communicate, can be showed from two aspects, they are oral communication and written communication. Speaking cannot be separated from human life. It is a practice of communication in which one can express ideas, feelings, or knowledge. Learning to speak is an essential activity of the whole process of learning experienced the learners. As in reading, learners also need to think about the main idea, supporting idea, and how supporting idea build the main ideas to convey the message or information. In general, the speaking components consist of accuracy, fluency, and comprehensibility.

\section{RESUlTS AND DisCUSSION}

The data were analyzed under the highlights of the research questions. The first research question was to analyze whether speaking ability improved after learning through task-based activities. The rating scores of the oral assessment forms were calculated and converted into mean scores, then checked to see whether or not the mean scores of the post-test were meaningful. The second research question was to examine whether the use of task-based learning was effective in improving students' speaking ability. The verbal ability scores in the post-test were computed and converted into mean scores. The steps of the data analysis process involved determining the means and the standard deviation of each student to check whether or not the mean scores of post-test were in the same way as expected. The third research question was to examine the students' opinions about the task-based learning and teaching activities.

The researcher analyzed the interviews after the stages of research findings. Since the TBL consist of 6 stages, then Willis (1996) simplified into three steps that are pre-task, post-task, and task-realization. Pre Task is suggested that lecturer as facilitator at this stage chosen material will need to relate the task and how much the learner will need language work he/she thinks and in this step the researcher use brainstorming. It could be initiated by making a list, comparing idea, and sharing experiences as a lead-in. The finding shows that involving students on the Task-based Learning strategy in speaking activity help them to improve their skill. This step is subject to place the students into three main activities of Task-Based learning method and giving benefit to explore ideas to say.

Post - Task Activity students are lead to reporting and conclude the topic. The lecturer provides pictures, chart, tables or many more, in the meaning of to stimulate students' perspective on topics given. The lecturer brings students' 
mind to figure out to where the topic is going to. Through Pre-task strategy, around $45 \%$ students said entirely agree when the lecturer drills various subject and it will affect various exercises too. Only $35 \%$ of students said agree and the rest $(10 \%)$ said not. The data indicate that the more various subjects the lecturer give, the more various exercises can be done. Almost $80 \%$ of students entirely agree that the topic is being discussed in the classroom, it brings the goal of the learning implicitly, only $20 \%$ of students said to agree. The topic which is being discussed in the learning process should become the trending topic in society, there are $65 \%$ entirely agree, only $10 \%$ agreed, and $25 \%$ were doubted. In applying the Task-based learning strategy at the classroom, there were $75 \%$ agree to say that in speaking class, vocabulary becomes the focus of government which relates to the topic only $20 \%$ say agree.

Task Realization, In conclusion, the data were shown, analyzed, and interpreted to interpret the findings of the study. The interpretations and the analysis were based on classroom participation and post-test scores. The findings of the research deal with students' achievement in speaking which cover students' accuracy, fluency, and Comprehensibility. Students Achievement in Pretest and Posttest regarding Accuracy, Fluency, and Comprehensibility. The comprehensibility in posttest was higher than the score in the pretest. Thus, study showed the significant difference between pretest without treatment and posttest after treatment through task-based language teaching. The questionnaire is designed to find out the students' attitude toward their English before and after the implementation of TBL. The questionnaire consisted of items the design book, learning activity and the affectivity toward task-based language in the process of speaking learning. Moreover, the questionnaire designed in the form of Likert scale. The options are strongly agreed, agree, undecided, disagree, and strongly disagree. In this case, the questionnaire consisted of 20 statements, where ten positive statements and ten negative statements. The questionnaire distributed after conducting the treatments to the students. Then the result as in the following Figure 2.

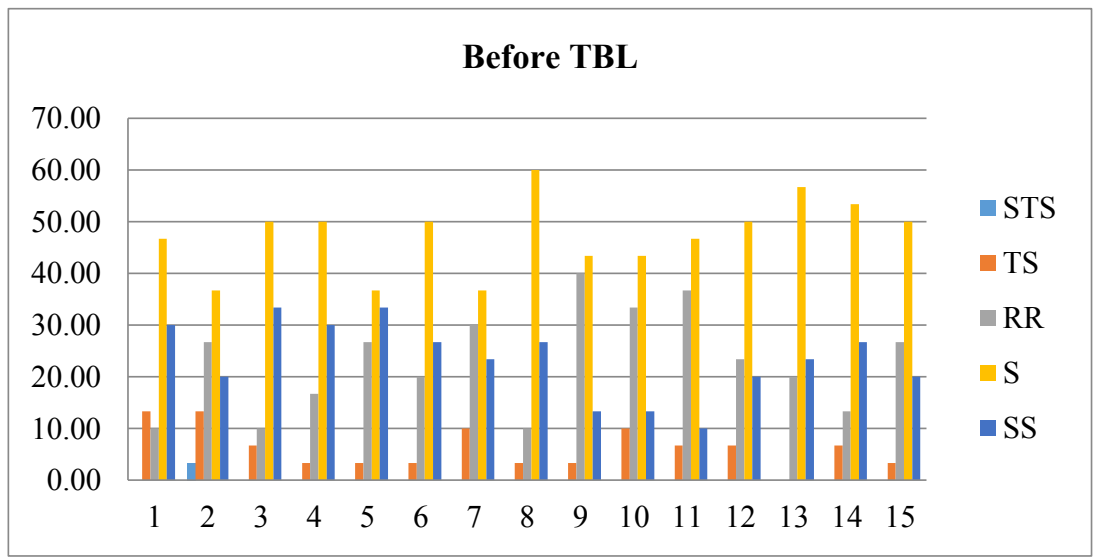

Figure 2. Before Implementing TBL 
Figure 2 above shows that before implementing TBL it can be seen that questionnaires was conducted to know the students perspective toward the TBL, based on the data gathered it could be concluded that content, organization, and design aspect affects the student's motivation to learn. Therefore most of the students agree the content of the book should be the same with the student's levels, the materials selected is one of the students respond, nearly all of the students like to have election, woman emancipation, cultural differences article to discuss during the learning process

The description of the data that collected in two components in speaking test, there were fluency and comprehensibility through the test showed that the students' achievement in speaking ability before doing the treatment was average. It could be demonstrated by the rate of percentage of the students' pre-test score in fluency where there were $8(40 \%)$ students got "poor" score, $9(45 \%)$ students got "Average" score, $2(10 \%)$ students got "good" score, $1(5 \%)$ students got "very good" score, no students got "very poor" score and it got $0(0 \%)$. The data showed that most students stated on two levels. The data showed that most of the students stated in two levels. There were one student got very good. There were two students got good, there were nine students got average, and eight students got poor. While the rate percentage and frequency of the students' pre-test result in speaking comprehensibility before having treatment through discussion method, there were $5(25 \%)$ students' got poor. $10(50 \%)$ students' got 'average.' 2 (10\%) students got 'good' score. $3(15 \%)$ students got 'very good' score, and there were no students got very poor score $0(0 \%)$. The data above showed that most students stated on two levels. The data showed that most of the students stated in two levels. There were three students got very good. There were two students got good, there were ten students got average, and five students got poor. However, by implementing TBL, EFL students' achievement increased in speaking skill as in the following Figure 3.

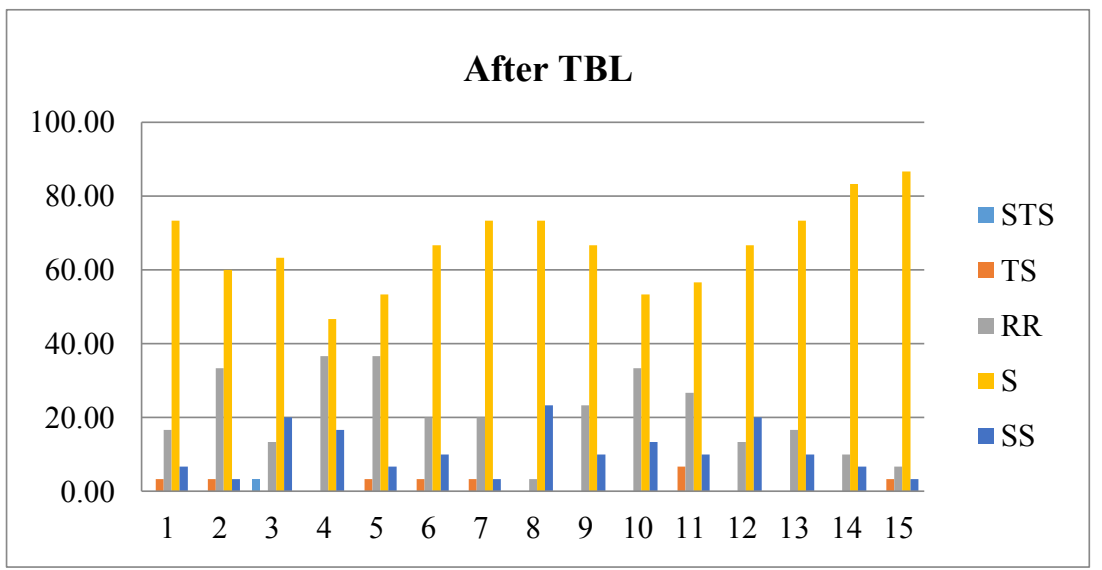

Figure 2. After Implementing TBL 
Figure 3 above indicates that after EFL students got treatments, their achievement in speaking was good. It was supported by the rate of percentage of the students' post-test in fluency, where there were 3(15\%) students got "very good" score, $12(60 \%)$ the students got "good" score, $5(25 \%)$ the students got "average" score, there were no students got "very poor" and "poor" score. Both of them got $0 \%$. Based on the data, the researcher concluded most students were at sound level. There were ten numbers of students of student frequencies. The rate percentage and frequency of the students' post-test result in speaking comprehensibility after having treatment through TBL method, there were $3(15 \%)$ students got 'very good' score, $12(60 \%)$ the students got 'good' score, 5 (25\%) the students got 'average' score, and there were no students got 'poor' and 'very poor' score. Both of their classifications got $0 \%$.

Furthermore, the achievement of EFL students in speaking skill is also measured by calculating the Mean Score and Standard Deviation. The result of the pretest of English achievement indicates that the mean score of 30 students took the test is 78.47 and posttest is 82.10 . This indicates that the score is increased after applying TBL, to sum up, TBL was an effective way of teaching English in improving speaking primarily for the students. It was demonstrated by seeing a significant difference between pre-test and post-test materials, as indicated in Table 1 below.

\begin{tabular}{ccccccc}
\hline & & & & $\begin{array}{c}\text { Std. } \\
\text { Deviation }\end{array}$ & $\begin{array}{c}\text { Std. } \\
\text { Mean }\end{array}$ & Error \\
\hline \multirow{2}{*}{1} & Pair & PRE & 78.47 & 30 & 1.78 & .32 \\
& & POST & 82.10 & 30 & 1.92 & .35 \\
\hline
\end{tabular}

Table 1 above indicates that the TBL score of the student's pre-test and post-test on the speaking. It could be seen that there were 15 students got score increased, five students got score unchanged, and no student had a low score. It means that $75 \%$ the students got an improvement of their score, $25 \%$ students did not get improvement and $0 \%$ students got lower-score. Based on the description above, it could be concluded that the achievement of the students' speaking ability through TBL in post-test was higher than the result of the rate percentage of the students' pre-test. This meant that TBL strategy could teach the students. The students result in pre-test and post-test of the students' speaking achievement could be showed in the students' mean score of both pre-test and post-test. The students mean score of fluency in pre-test was 2,8, and the students' mean score of comprehensibility was 3,15 . The total students' mean score in pre-test was 5,95. In post-test, the students' mean score of fluency was 3,8 , and the students mean score of comprehensibility was 3,9 the total students' mean score in post-test was 7,7.

Comparing the total mean score of students in pre-test and post-test, it could be concluded that the total students' mean score in post-test was higher than the total students mean score in the pre-test. In other words, it could be said that 7,7 $>5,95$. The t-test and t-table should compare the value. The t-test of this research was 12,25 while the t-table in this research was 2,093. T-table 
in this research was smaller than the t-test. Based on the result of the t-test, the researcher found that there was a significant difference between the result of pre-test and post-test. The difference was seen after comparing the value of $t$ test and t-table. This meant that there was significant difference result of the test after teaching and learning process through Task-Based Learning. The result of questionnaires design, based on the question given related to TBL that students believe it helped them to improve their communication skill in English with the help of error correction by the lecturer, by interesting study subject and opinion sharing. Therefore, there were varieties of answer for the type of activities like making a poster, general election, women emancipation, LGTB and cultural differences also making a presentation and debate is the most helpful activity to share.

\section{Conclusion}

After applying TBL strategy, it is indicating that speaking tasks which the participants studied in the classroom helped them to improve their communication skills in English because they say the lecturer helped them to correct their mistakes in the learning process. However, some of them stated that these tasks should be implemented more in the classroom environment, and the topics should be interesting enough for the active participation. Throughout the learning process, the students were generally motivated by the listening and speaking tasks given by the lecturer. Students mostly worked in pairs and as a group. During the course steps, the learners helped each other and engaged in the activities. Nevertheless, motivation is one of the significant determination speaks up. In this case, the researcher was a guide and a facilitator in the classroom environment. She wanted to improve her students' communicative competence in engaging the task-based activities from pre-task up to post-task. Therefore, this helped the students to feel relaxed and comfortable throughout the process.

The purpose of the study was to analyze the use of task-based learning to develop speaking abilities through task-based activities in EFL context and to examine students' opinions about the use of these activities in the classroom. To sum up, TBL was an effective way of teaching English in improving speaking mainly for the students. It was demonstrated by seeing a significant difference between pre-test and post-test.

\section{REFERENCES}

Atkinson, R. H., \& Longman, D. G. (2002). Reading Enhancement and Development. Thomson Learning.

Gustafson, K. L., \& Branch, R. M. (2002). Survey of Instructional Development Models. ERIC Clearinghouse on Information and Technology.

Hamra, A., \& Syatriana, E. (2010). Developing a model of teaching reading comprehension for EFL students. TEFLIN Journal, 21(1), 27.

Krashen, S. D. (2015). Remarks on language acquisition and literacy: language acquisition and teaching, free reading," test-prep" and its consequences, the use of the first language, writing, and the great native speaker teacher 
debate. Indonesian JELT, 10(1), 1-17.

Lao, C., \& Krashen, S. (2014). Language acquisition without speaking and without study. Journal of Bilingual Education Research and Instruction, 16(1), 215-221.

Nunan, D. (2016). Language teacher identity in teacher education. Reflections on Language Teacher Identity Research, 164.

Nunan, D. (2018). Teaching Speaking to Young Learners. The TESOL Encyclopedia of English Language Teaching, 1-8.

Nunan, D., \& Richards, J. C. (2015). Language learning beyond the classroom. Routledge.

Saville-Troike, M., \& Barto, K. (2016). Introducing second language acquisition. Cambridge University Press.

Silberman, M. (1996). Active Learning: 101 Strategies To Teach Any Subject. ERIC.

Syatriana, E., Husain, D., Haryanto, H., \& Jabu, B. (2013). A model of creating instructional materials based on the school curriculum for Indonesian secondary school. Journal of Education and Practice. Pág, 10-18.

Willis, J. (1996). A flexible framework for task-based learning. Challenge and Change in Language Teaching, 52-62. 